\title{
FAKTOR YANG BERHUBUNGAN DENGAN KEJADIAN ANEMIA PADA IBU HAMIL BERKUNJUNG DI PUSKESMAS SUDIANG KOTA MAKASSAR
}

\author{
Arlina Muhtar \\ STIKESNani Hasanuddin Makassar \\ (Alamat Korespondesi: arlinafr@gmail.com/08114166282)
}

\begin{abstract}
ABSTRAK
Anemia adalah suatu kondisi medis di mana jumlah sel darah merah atau hemoglobin kurang dari normal. Kurang asupan zat besi pada perempuan khususnya ibu hamil dapat menyebabkan anemia yang akan menambah risiko perdarahan dan melahirkan bayi dengan berat lahir rendah, prevalensi anemia pada ibu hamil sekitar 37,1\% Riset Kesehatan Dasar (Riskesdas, 2013). Tujuan penelitian ini adalah untuk mengetahui faktor yang berhubungan dengan kejadian anemia pada ibu hamil yang datang berkunjung di Puskesmas Sudiang Kota Makassar. Jenis penelitian adalah Cross sectional study dengan sampel berjumlah 78 responden. Pengumpulan data dilakukan dengan cara primer dan sekunder yaitu melihat faktor yang berhubungan dengan kejadian anemia pada ibu hamil melalui wawancara dengan alat bantu kuesioner dan di analisis dengan uji chi square $(p \leq 0,05)$. Hasil penelitian diperoleh $46,2 \%$ responden mengalami anemia, 52,6\% responden dengan pengetahuan cukup, $59,0 \%$ responden dengan pendapatan keluarga rendah, $56,4 \%$ responden dengan status gizi kurang. Kesimpulannya ada hubungan antara pendapatan keluarga dengan anemia pada ibu hamil $(p \leq 0,028)$, ada hubungan antara status gizi dengan anemia pada ibu hamil $(p \leq 0,009)$ dan tidak ada hubungan antara pengetahuan dengan anemia pada ibu hamil $(p \leq 0,074)$, maka perlu diketahui faktor yang berhubungan dengan kejadian anemia selama kehamilan. Serta perlu adanya peningkatan pengetahuan tentang asupan gizi yang baik pada saat hamil.
\end{abstract}

Kata Kunci: Pengetahuan, Pendapatan Keluarga, Status Gizi, dan Anemia pada ibu Hamil

\section{PENDAHULUAN}

Strategi pembangunan kesehatan menuju indonesia sehat 2015 mengisyaratkan bahwa pembangunan kesehatan ditunjukan pada upaya menyehatkan bangsa. Salah satu indikator hasilnya adalah angka kematian ibu (AKI). Penyebab terbesar AKI adalah perdarahan, dan salah satu penyebab perdarahan adalah anemia, terutama dalam kehamilan. Anemia dalam kehamilan adalah kondisi ibu dengan kadar hemoglobin dibawah 11 gram\% pada trimester 1 dan 3 atau kadar < 10,5 gram \% pada trimester 2. Nilai batas tersebut dan perbedaannya dengan kondisi tidak hamil terjadi karena hemodilusi (pengenceran darah), terutama pada trimester 2 (Prawiroharjo, 2010. Dikutip oleh Fikriana, 2014).

Anemia adalah masalah kesehatan masyarakat dunia yang dapat meningkatkan angka morbiditas dan mortalitas. Angka prevalensi anemia masih tinggi, dibuktikan dengan data World Health Organizatin (WHO) 2010, yaitu secara global prevalensi anemia pada ibu hamil di seluruh dunia adalah sebesar $41,8 \%$. Prevalensi anemia pada ibu hamil di perkirakan di Asia sebesar 48,2\%, Afrika 57,1\%, Amerika 24,1\% dan Eropa 25,1\%. Di negara-negara berkembang ada sekitar $40 \%$ kematian ibu berkaitan dengan anemia dalam kehamilan. Kebanyakan anemia dalam kehamilan disebabkan oleh defisiensi besi dan perdarahan akut, bahkan, jarak keduanya saling berinteraksi (Rizqi Ariyani, 2016).

Anemia pada umumnya terjadi di seluru dunia, terutama di Negara berkembang dan pada kelompok sosial ekonomi rendah. Pada kelompok dewasa, anemia terjadi pada wanita usia reproduksi, terutama wanita hamil dan wanita menyusui karena mereka yang banyak mengalami defisiensi fe. Secara meseluruhan, anemia terjadi pada $45 \%$ wanita di Negara berkembang dan $13 \%$ di negara maju. Di amerika, terdapat $12 \%$ wanita usia subur (WUS) 15-49 tahun, dan $11 \%$ wanita hamil usia subur mengalami anemia. Sementara persentase wanita hamil dari keluarga miskin terus meningkat seiring bertambahnya usia kehamilan ( $8 \%$ anemia di trimester I, $12 \%$ anemia di trimester II, dan 29\% anemia di trimester III (Fatmah, 2012 dikutip oleh Diana Sukmaningtyas, 2015).

Ibu mengalami perubahan yang signifikan saat hamil. Jumlah darah dalam tubuh meningkat sekitar $20-30 \%$, sehingga memerlukan peningkatan kebutuhan pasokan besi dan vitamin untuk membuat hemoglobin. Ketika hamil, tubuh membuat lebih banyak 
darah untuk berbagi dengan bayinya. Tubuh mungkin memerlukan darah hingga 30\% lebih banyak daripada ketika tidak hamil. Jika tubuh tidak memiliki cukup zat besi, tubuh tidak dapat membuat sel-sel darah merah yang dibutuhkan untuk membuat darah ekstra. Hemoglobin adalah protein dalam sel darah merah yang membawa oksigen ke sel-sel lain dalam tubuh. Banyak wanita yang mengalami defisiensi besi pada trimester kedua dan ketiga. Ketika tubuh membutuhkan lebih banyak zat besi dibandingkan dengan yang telah tersedia, maka dapat berpotensi terjadinya anemia (Proverawati, 2011).

Anemia adalah suatu kondisi medis di mana jumlah sel darah merah atau hemoglobin kurang dari normal. Kadar hemoglobin normal umumnya berbeda pada laki-laki dan perempuan. Untuk pria, anemia biasanya didefinisikan sebagai kadar hemoglobin kurang dari $13,5 \mathrm{gram} / 100 \mathrm{ml}$ dan pada wanita sebagai hemoglobin kurang dari $12,0 \mathrm{gram} / 100 \mathrm{ml}$ (Proverawati, 2011).

Masalah anemia pada masyarakat dan berdampak pada perkembangan fisik, sosial ekonomi khususnya ibu hamil dan bayi yang dikandungnya serta tingginya prevalensi anemia pada ibu hamil yang datang berkunjugn di puskesmas sudiang maka peneliti tertarik untuk mengetahui faktor apa saja yang berhubungan dengan kejadian anemia pada ibu hamil yang datang berkunjung di puskesmas sudiang kota makassar.

\section{BAHAN DAN METODE}

\section{Lokasi, Populasi, dan Sampel}

Jenis penelitian ini adalah menggunakan metode deskriptif analitik dengan menggunakan pendekatan "cross sectional" dengan tujuan penelitian ini adalah untuk mengetahui faktor yang berhubungan dengan kejadian anemia pada ibu hamil yang datang berkunjung di puskesmas sudiang kota Makassar.

Telah dilaksanakan di Puskesmas Sudiang Kota Makassar pada tanggal 13 juni13 juli 2017. Populasi dalam penelitian ini adalah seluruh ibu hamil yang datang berkunjung di Puskesmas Sudiang Kota Makassar. Pada bulan September-desember 2016 sebanyak 97 orang dengan jumlah sampel pada penelitian ini adalah 78 orang.

Adapun kriteria dari sampel sebagai berikut :

1. Kriteria inklusi

a. Ibu hamil yang mengalami anemiayang bersedia menjadi responden.

b. Ibu hamil yang mengalami anemia yang datang di puskesmas sudiang.

c. Ibu hamil yang mengalami anemia yang datang periksa di puskesmas sudiang.
2. Kriteria eksklusi

a. Ibu hamil yang mengalami anemia yang tidak bersedia menjadi responden.

b. Ibu hamil yang mengalami anemia yang tidak datang di puskesmas sudiang pada saat penelitian.

c. Ibu hamil yang mengalami anemia yang tidak datang periksa di puskesmas sudiangpadasaatpenelitian.

\section{Pengumpulan Data}

1. Editing

Editing atau penyuntingan data mulai dilakukan pada saat penelitian yaitu memeriksa semua angka yang telah diisi, mengenai kekurangan dan cara pengisian.

2. Kegiatan yang dilakukan berupapemberian kode berupa angka 1, 2, 3 dan seterusnya kepada setiap kuesioner yang telah diisi oleh responden.

3. Tabulasi Data

Tabulasi data merupakan kelanjutan dari pengkodean pada proses pengolahan, dalam hal ini setelah data tersebut dikoding kemudian di tabulasi agar lebih mempermudah penyajian data dalam bentuk distribusi frekuensi.

Analisis data

1. Analisis Univariat (Analisis Deskriptif)

Analisis univariat bertujuan untuk menjelaskan atau mendeskripsikan karakteristik setiap variabel penelitian. Bentuk analisis univariat tergantung dari jenis datanya.

2. Analisis bivariat

Analisis bivariat yang dilakukan terhadap dua variabel yang diduga berhubungan atau berkolerasi.

\section{HASIL PENELITIAN}

1. Analisis Univariat

Tabel 1 Distribusi Frekuensi responden berdasarkan Umur yang datang berkunjugn di Puskesmas Sudiang Kota Makassar

\begin{tabular}{|l|c|c|}
\hline \multicolumn{1}{|c|}{ karakteristik } & $\mathrm{n}$ & $\%$ \\
\hline Umur & & \\
$15-25$ & 43 & 55,1 \\
$26-35$ & 31 & 39,7 \\
$36-45$ & 4 & 5,2 \\
\hline Pendidikan & & \\
SD & 6 & 7,7 \\
SMP & 22 & 28,2 \\
SMA & 43 & 55,1 \\
Perguruan Tinggi & 7 & 9,0 \\
\hline
\end{tabular}

Dari Tabel 1 menunjukkan bahwa dari 78 responden sebagian besar berumur 1525 tahun sebanyak 43 orang $(55,1 \%)$ responden, umur 26-35 tahun sebanyak 31 
orang $(39,7 \%)$ responden, dan umur $36-45$ tahun sebanyak 4 orang $(5,2 \%)$ responden. Dari 78 responden yang berpendidikan SD sebanyak 6 orang $(7,7 \%)$ responden, SMP sebanyak 22 orang $(28,2 \%)$ responden, SMA sebanyak 43 orang (55,1\%) responden, dan perguruan tinggi sebanyak 7 orang $(9,0 \%)$.

\section{Analisis Bivariat}

Tabel 2.Hubungan antara Pengetahuan dengan Anemia pada Ibu hamil yang datang berkunjung di Puskesmas Sudiang Kota Makassar.

\begin{tabular}{|c|c|c|c|c|c|c|}
\hline \multirow{3}{*}{ Pengeta huan } & \multicolumn{4}{|c|}{$\begin{array}{c}\text { Anemia Pada } \\
\text { Ibu Hamil }\end{array}$} & \multirow{2}{*}{ Total } \\
\cline { 2 - 6 } & \multicolumn{2}{|c|}{ Tidak } & \multicolumn{2}{|c|}{ Ya } & \multicolumn{1}{c|}{} \\
\cline { 2 - 7 } & $\mathrm{n}$ & $\%$ & $\mathrm{n}$ & $\%$ & $\mathrm{n}$ & $\%$ \\
\hline Kurang & 27 & 34,6 & 14 & 17,9 & 41 & 52,6 \\
\hline Baik & 16 & 20,5 & 21 & 26,9 & 37 & 47,4 \\
\hline Total & 43 & 55,1 & 35 & 44,9 & 78 & 100,0 \\
\hline \multicolumn{6}{|c|}{$\alpha=0,05$} & $p=0,045$ \\
\hline
\end{tabular}

Dari Tabel 2 menunjukkan bahwa dari 78 orang responden, terdapat 41 orang $(52,6 \%)$ responden memiliki pengetahuan kurang dan dari data tersebut terdapat 27 orang $(34,6 \%)$ responden tidak mengalami anemia dan 14 orang $(17,9 \%)$ responden didiagnosa mengalami anemia. Sedangkan responden yang memiliki pengetahuan baik sebanyak 37 orang $(47,4 \%)$ responden, dan dari data tersebut terdapat 16 orang $(20,5 \%)$ responden tidak mengalami anemia dan 21 orang $(26,9 \%)$ responden mengalami anemia.

Berdasarkan uji statistik dengan menggunakan chi-square diperoleh nilai $p$ $(0,045)$ lebih kecil dari $<\alpha(0,05)$ yang menunjukkan penolakan terhadap hipotesis noll (Ho) dan penerimaan terhadap hipotesis alternative (Ha). Dapat disimpulkan bahwa ada hubungan antara pengetahuan dengan kejadian anemia pada ibu hamil di Wilayah kerja Puskesmas Sudiang Kota Makassar.

Tabel 3, Hubungan antara Pendapatan Keluarga dengan Anemia ada Ibu Hamil yang datang berkunjung di Puskesmas Sudiang Kota Makassar

\begin{tabular}{|c|c|c|c|c|c|c|}
\hline \multirow{2}{*}{$\begin{array}{c}\text { Pendapatan } \\
\text { keluarga }\end{array}$} & \multicolumn{3}{|c|}{ Anemia Pada Ibu Hamil } & \multirow{2}{*}{ Total } \\
\cline { 2 - 6 } & \multicolumn{2}{|c|}{ Tidak } & \multicolumn{2}{|c|}{ Ya } & \\
\cline { 2 - 6 } & $\mathrm{n}$ & $\%$ & $\mathrm{n}$ & $\%$ & $\mathrm{n}$ & $\%$ \\
\hline Rendah & 21 & 26,9 & 25 & 32,1 & 46 & 59,0 \\
\hline Tinggi & 22 & 28,2 & 10 & 12,8 & 32 & 41,0 \\
\hline Total & 43 & 55,1 & 35 & 44,9 & 78 & 100,0 \\
\hline \multicolumn{8}{|c|}{$\alpha=0,05$} & $p=0,044$ \\
\hline
\end{tabular}

Dari Tabel 3 menunjukkan bahwa dari 78 orang responden, terdapat 46 orang $(59,0 \%)$ responden memiliki pendapatan keluarga rendah dan dari data tersebut terdapat 21 orang $(26,9 \%)$ responden tidak mengalami anemia, dan 25 orang $(32,1 \%)$ responden mengalami anemia. Sedangkan responden yang memiliki pendapatan keluarga tinggi sebanyak 32 orang $(35,9 \%)$ responden, dan dari data tersebut terdapat 22 orang $(28,2 \%)$ responden tidak mengalami anemia, dan 10 orang (12,8\%) responden mengalami anemia.

Berdasarkan uji statistic dengan menggunakan chi-square diperoleh nilai $p$ $(0,044)<\alpha \quad(0,05)$ yang menunjukkan penolakan terhadap hipotesis noll (Ho) dan penerimaan terhadap hipotesis alternative (Ha). Dapat disimpulkan bahwa ada hubungan antara pendapatan keluarga dengan kejadian anemia pada ibu hamil di Wilayah kerja Puskesmas Sudiang Kota Makassar.

Tabel 4, Hubungan antara Status Gizi denagn Anemia pada Ibu Hamil yang datang berkunjung di Puskesmas Sudiang Kota Makassar.

\begin{tabular}{|c|c|c|c|c|c|c|}
\hline \multirow{2}{*}{ Status Gizi } & \multicolumn{3}{|c|}{ Anemia Pada lbu Hamil } & \multirow{2}{*}{ Total } \\
\cline { 2 - 6 } & \multicolumn{2}{|c|}{ Tidak } & \multicolumn{2}{|c|}{ Ya } & \multicolumn{1}{c|}{} \\
\cline { 2 - 6 } & $\mathrm{n}$ & $\%$ & $\mathrm{n}$ & $\%$ & $\mathrm{n}$ & $\%$ \\
\hline Kurang & 19 & 24,4 & 25 & 32,1 & 44 & 56,4 \\
\hline Baik & 24 & 30,8 & 10 & 12,8 & 34 & 43,6 \\
\hline Total & 43 & 55,1 & 35 & 44,9 & 78 & 100,0 \\
\hline \multicolumn{6}{|c|}{$\alpha=0,05$} & $p=0,016$ \\
\hline
\end{tabular}

Dari Tabel 4 menunjukkan bahwa dari 78 orang responden, terdapat 44 orang $(56,4 \%)$ responden mengalami status gizi kurang, dan dari data tersebut terdapat 19 orang $(24,4 \%)$ responden tidak mengalami anemia, dan 25 orang $(32,1 \%)$ responden mengalami anemia. Sedangkan responden yang memiliki status gizi baik sebanyak 34 orang $(43,6 \%)$ responden, dan dari data tersebut terdapat 24 orang $(30,8 \%)$ responden tidak mengalami anemia, dan 10 orang $(12,8 \%)$ responden mengalami anemia.

Berdasarkan uji statistik dengan menggunakan chi-square diperoleh nilai $p$ $(0,016)$ lebih kecil dari <a $(0,05)$ yang menunjukkan penolakan terhadap hipotesis noll (Ho) dan penerimaan terhadap hipotesis alternative (Ha). Dapat disimpulkan bahwa ada hubungan antara Status Gizi dengan kejadian anemia pada ibu hamil di Wilayah kerja Puskesmas Sudiang Kota Makassar. 


\section{PEMBAHASAN}

1. Hubungan pengetahuan dengan anemia pada ibu hamil.

Berdasarkan analisia univariat menunjukkan bahwa jumlah responden memiliki pengetahuan kurang sebanyak 41 responden $(52,6 \%)$ dan responden yang memiliki pengetahuan baik sebanyak 37 responden $(47,4 \%)$. Sedangkan analisa bivariat menunjukkan hasil uji Chi-square $p=0,045<\alpha=0,05$, maka Ho ditolak dan $\mathrm{Ha}$ diterima atau ada hubungan yang bermakna antara pengetahuan dengan anemia pada ibu hamil.

Pengetahuan adalah merupakan hasil "tahu" dan ini terjadi setelah orang mengadakan penginderaan terhadap suatu obyek tertentu. Penginderaan terhadap obyek terjadi melalui panca indra manusia yakni penglihatan, pendegaran, penciuman, rasa dan raba dengan sendiri. Pada waktu penginderaan sampai mengasilkan pengetahuaan tersebut sangat dipengaruhi oleh intensitas perhatian persepsi terhadap obyek (Wawan \& Dewi 2011).

Penelitian ini sejalan dengan penelitian yang dilakukan oleh Diana Sukmaningtyas (2015) yang mengatakan Meskipun pengetahuan tinggi tapi tidak mengaplikasikan pengetahuan yang mereka ketahui, maka bisa juga menyebabkan status gizinya menjadi kurang.Meskipun pengetahuan ibu hamil tinggi, namun keadaan sosial ekonominya tidak mendukung untuk memenuhi kebutuhan akan konsumsi makanan yang mengandung zat besi.

Menurut (Soraya 2013, dikutip oleh Diana Sukmaningtyas, 2015) usia, pendidikan, pendapatan, pengalaman serta sumber informasi dapat memperngaruhi pengetahuan seseorang. Sistem sosial budaya masyarakat setempat pun secara tidak langsung akan mempengaruhi pengetahuan seseorang, karena sistem sosial budaya akan mempengaruhi sikap seseorang dalam menerima informasi.

Maka peneliti berkesimpulan bahwa adanya hubungan antara pengetahuan dengan anemia pada ibu hamil. Karena engetahuan itu sendiri di pengaruhi oleh faktor pendidikan formal. Pengetahuan sangat erat hubungannya dengan pendidikan, dimana di harapkan bahwa dengan pendidikan yang tinggi maka orang tersebut akan semakin luas pula pengetahuannya tentang anemia.

2. Hubungan pendapatan keluarga dengan anemia pada ibu hamil

Berdasarkan analisa univariat menunjukkan bahwa jumlah responden dengan pendapatan keluarga rendah sebanyak 46 responden $(59,0 \%)$ dan responden yang memiliki ekonomi tinggi sebanyak 32 responden $(41,0 \%)$. Sedangkan analisa bivariat menunjukkan hasil $p=0,044<\alpha=0,05$ Maka Ho ditolak dan $\mathrm{Ha}$ diterimah atau ada hubungan yang bermakna antara pendapatan keluarga dengan kejadian anemia pada ibu hamil.

Status ekonomi adalah suatu kedudukan yang diatur secara sosial dan menempatkan seseorang pada posisi tertentu. Menurut (Proverawati, 2011) status ekonomi adalah salah satu faktor yang mempengaruhi status gizi pada ibu hamil.

Penelitian ini sejalan dengan penelitian Suhardjo, dikutip oleh Dian Handini (2013) mengatakan hal ini sesuai dengan kepustakaan yang menyatakan bahwa kemiskinan sebagai penyebab gizi kurang menduduki posisi pertama pada kondisi yang umum.

Penelitian ini sejalan dengan penelitian Manuaba, dikutip oleh Ita Purwanti (2012), tingkat sosial ekonomi yang rendah akan mempengaruhi seseorang untuk terkena anemia karena jumlah zat-zat gizi tertentu yang dibutuhkan tidak terpenuhi, karena tidak ada uang yang dapat digunakan untuk memenuhi kebutuhan tersebut. Anemia dalam kehamilan merupakan masalah nasional karena mencerminkan nilai kesejahteraan sosial ekonomi masyarakat dan pengaruhnya sangat besar terhadap kualitas sumber daya manusia.

Dari hasil penelitian diatas maka peneliti berkesimpulan bahwa tidak adanya hubungan antara pendapatan keluarga dengan anemia pada ibu hamil, karena berapapun pendapatan seseorang tidak akan menyebabkan terjadinya anemia jika ibu tersebut rajin meminum tablet fe dan menjaga kesehatannya.

3. Hubungan status gizi dengan anemia pada ibu hamil

Berdasarkan analisa univariat menunjukkan bahwa jumlah responden dengan status gizi kurang sebanyak 44 ressponden $(56,4 \%)$, dan responden yang memiliki status gizi baik sebanyak 34 responden $(43,6 \%)$. Sedangkan analisa bivariat menunjukkan hasil $p=0,016<\alpha=0,05$, maka Ho ditolak dan Ha diterima atau ada hubungan yang bermakna antara status gizi dengan anemia pada ibu hamil.

Hasil ini sejalan dengan teori Mardalena (2017) yang menyatakan bahwa Kebutuhan ibu hamil akan zat besi dapat 
meningkat hingga 200-300\% dibandingkan wanita tidak hamil. Zat besi berfungsi di dalam pembentukan darah. Sehingga memenuhi asupan zat besi bagi ibu hamil akan mengurangi resiko terkena anemia.

Penelitian ini sejalan dengan penelitian yang telah dilakukan oleh Diana Sukmaningtyas (2015) yang menunjukkan ada hubungan antara status gizi dengan kejadian anemia, hal ini dapat disebabkan karena konsumsi asupan makanan yang kurang mengandung zat besi, bisa juga karena faktor ekonomi, infeksi maupun konsumsi makanan atau minuman penghambat penyerapan zat besi. Penelitian ini sejalan dengan penelitian (Waryana, 2010, dikutip oleh Diana Sukmaningtyas, 2015), yang mengatakan kekurangan zat besi dapat menimbulkan gangguan atau hambatan pada pertumbuhan janin baik sel tubuh maupun sel otak. Anemia gizi dapat mengakibatkan kematian janin didalam kandungan, abortus, cacat bawaan, BBLR dan anemia pada bayi yang dilahirkan. Pada ibu hamil yang menderita anemia berat dapat meningkatkan resiko mordibitas maupun mortalitas ibu dan bayi, kemungkinan melahirkan bayi BBLR dan premature.

Maka peneliti berkesimpulan bahwa adanya hubungan antara status gizi dengan anemia pada ibu hamil, Karena jika serorang ibu yang sedang hamil kekurangan energi dan protein maka ibu tersebut cenderung mengalami anemia dan akan membahayakan bagi janin yang dikandungnya, maka dianjurkan untuk ibu hamil untuk mengkonsumsi makanan yang bergizi, seperti buah-buahan, sayuran dan daging.

\section{KESIMPULAN}

1. Terdapat hubungan yang signifikan antara Pengetahuan dengan Anemia pada ibu hamil $p(0,074)<\alpha(0,05)$

2. Terdapat hubungan yang signifikan antara pendapatan keluarga dengan Anemia pada ibu hamil $p(0,028)<\alpha(0,05)$

3. Terdapat hubungan yang signifikan antara Status gizi dengan Anemia pada ibu hamil $p$ $(0,009)<\alpha(0,05)$

\section{SARAN}

1. Bagi petugas kesehatan Puskesmas Sudiang Kota Makassar

Mengingat masih tingginya kejadian anemia pada ibu hamil diharapkan petugas kesehatan dapat memberikan penyuluhan tentang cara pencegahan timbulnya anemia, baik berupa pola konsumsi yang baik dan cara menjaga kesehatan selama kehamilan.

2. Bagi Peneliti

Kepada peneliti selanjutnya dapat melakukan penelitian lebih lanjut dengan melakukan pengkajian analitik yang lebih mendalam sehingga dapat dihasilkan hasil yang benar-benar faktual tentang pengetahuan, status gizi dalam hubungannya dengan kejadian anemia pada ibu hamil.

\section{DAFTAR PUSTAKA}

Ariyani, R. 2016. Faktor-Faktor Yang Mempengaruhi Kejadian Anemia Pada lbu Hamil Trimester III Di Puskesmas Mojolaba Kabupaten Sukoharjo.

A Wawan dan Dewi M, 2011. Pengetahuan, sikap dan perilaku manusia. Yogyakarta: Nuha Medical.

Fikriana, U. 2013. Faktor-Faktor Yang Mempengaruhi Kejadian Anemia Pada Ibu Hamil Di puskesmas Kasihan II Bantul.

Handini, D. 2013. Hubungan Tingkat Pendapatan Keluarga Dengan Status Gizi Balita Di Wilayah Kerja Puskesmas Kalijambe

Mardalena, I. 2017. Dasar-dasar ilmu gizi dalam Keperawatan. Yogyakarta : Perpustakaan Nasional RI.

Proverawati, A. 2011. Anemia Dan Anemia Kehamilan. Yogyakarta: Nuha Medika

Purwanti, I. Vol, 2. No, 2, Mei 2014. Pengetahuan Tentang Nutrisi Berhubungan Dengan Status Anemia Pada Ibu Hamil di Puskesmas Sewon II Bantul Yogyakarta.

Sukmanintyas, D. 2015. Hubungan Antara Tingkat Pengetahuan dan Status Gizi Ibu Hamil Dengan Kejadiab Anemia di Puskesmas Gatak. Fakultas ilmu Kesehatan Surakarta. 